\title{
A hot, swollen joint without trauma: septic arthritis until proven otherwise
}

\section{Amelia Sophie Oliveira, ${ }^{1}$ Faisal Abbasi, $^{2}$ Sarkhell Saadi Radha ${ }^{3}$}

${ }^{1}$ University College Hospital, London, UK

${ }^{2}$ East and North Hertfordshire NHS Trust, Stevenage, UK

${ }^{3}$ Department of Trauma and Orthopaedics, East and North Hertfordshire NHS Trust,

Stevenage, UK

\section{Correspondence to} Dr Faisal Abbasi,

faisal.abbasi@nhs.net

Accepted 7 March 2015
CrossMark

To cite: Oliveira AS,

Abbasi F, Radha SS. BMJ

Case Rep Published online:

[please include Day Month

Year] doi:10.1136/bcr-2014209190

\section{DESCRIPTION}

A 71-year-old man with a history of rheumatoid arthritis presented to the accident and emergency department with a hot, swollen and painful right knee. The patient had been seen by his primary care physician several times in the preceding 4 months, and each time oral antibiotics and
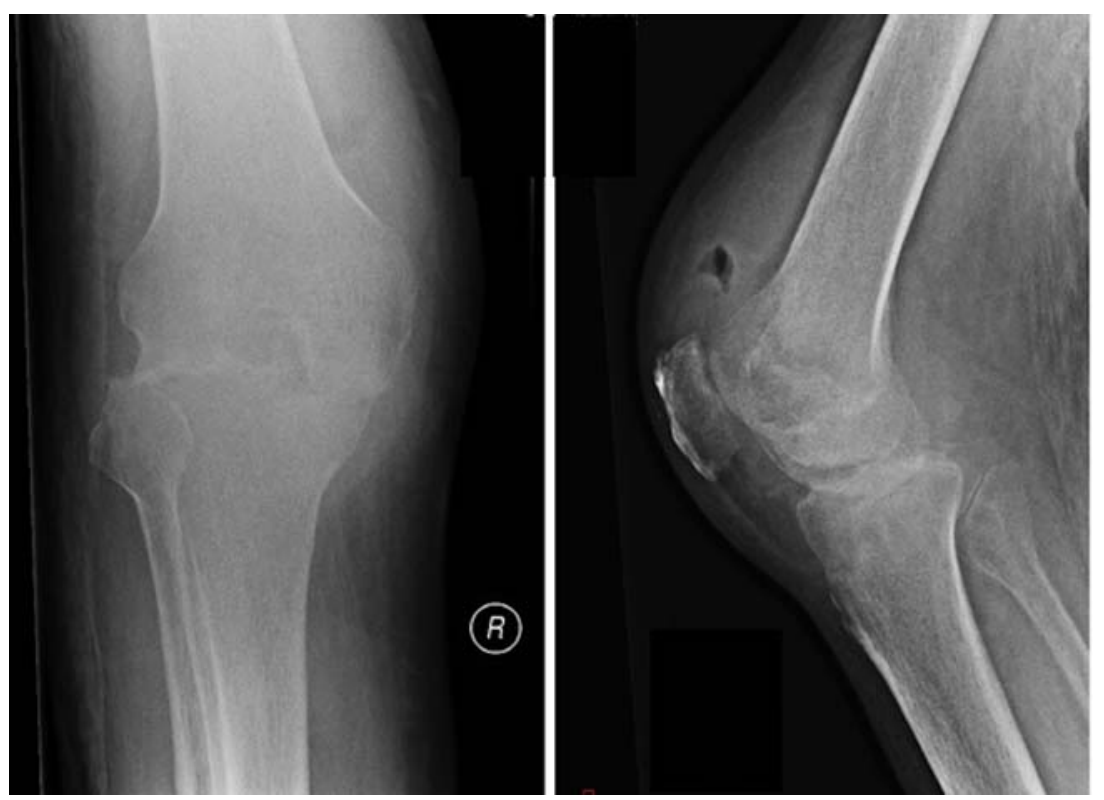

Figure 1 Anteroposterior and lateral right knee $\mathrm{X}$-ray showing tri-compartmental joint space narrowing with erosion of the subchondral surfaces.
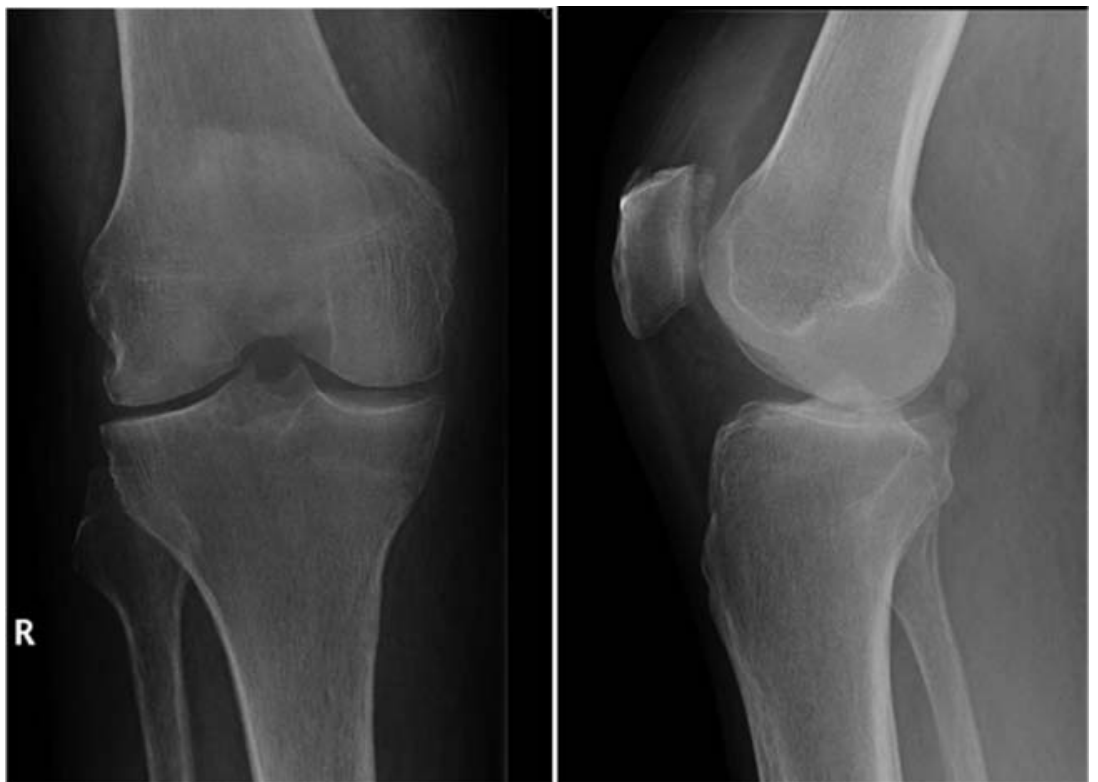

Figure 2 Anteroposterior and lateral right knee X-ray 3 months prior to hospital admission. 
$5-20^{\circ}$ range of movement in the right knee. The knee was hot and tender with no further joint involvement. Blood tests revealed $\mathrm{C}$ reactive protein $255 \mathrm{mg} / \mathrm{L}$, white cell count $12.4 \times 10^{9} / \mathrm{L}$ and a normal uric acid level. Radiographs demonstrated rapidly progressive tri-compartmental joint space narrowing with erosion of the subchondral surfaces (figures 1 and 2).

Suspecting septic arthritis, arthrocentesis of the knee was performed. This revealed frank pus from which Staphylococcus aureus was isolated with no crystals seen. Owing to an aspirate appearance and clinical sepsis, urgent arthroscopic washout was performed without synovial fluid cell count. Arthroscopy revealed copious pus in the joint space with widespread

\section{Learning points}

- Septic arthritis is a medical emergency that, if left untreated, can result in joint destruction, osteomyelitis, sepsis and death. $^{3}$

- Clinicians should maintain a high level of suspicion for septic arthritis in a patient with a history of rheumatoid arthritis presenting with a hot and swollen joint, especially without associated trauma. ${ }^{2}$

- Diagnosis and management of such a joint should be undertaken as a matter of urgency. destruction of the articular cartilage. Intravenous flucloxacillin was started for 6 weeks.

A painful and swollen joint is a common presentation to primary and secondary care. The association of rheumatoid arthritis and septic arthritis is well known. ${ }^{1}$ Regardless of the underlying inflammatory disease, a hot, swollen joint, especially without associated trauma, should be regarded as septic arthritis until proven otherwise. ${ }^{2}$ Early diagnosis and prompt treatment are key to the prevention of joint destruction.

Acknowledgements The authors thank all staff members in the X-ray and Orthopaedic Departments at The Lister Hospital.

Contributors All the authors were involved in the care of the patient. Relevant images and information from the clinical notes were collected by FA. ASO collated the information and wrote the report. This was reviewed and edited by SSR who also wrote the figure captions.

\section{Competing interests None.}

Patient consent Obtained.

Provenance and peer review Not commissioned; externally peer reviewed.

\section{REFERENCES}

1 Al-Ahaideb A. Septic arthritis in patients with rheumatoid arthritis. J Orthop Surg Res 2008:3:33.

2 Preslar AJ III, Hekman JD. Emergency department evaluation of the swollen joint. Emerg Med Clin North Am 1984;2:425-40.

3 Kaandorp CJ, Krijnen P, Moens HJ, et al. The outcome of bacterial arthritis: a prospective community-based study. Arthritis Rheum 1997;40:884-92.

Copyright 2015 BMJ Publishing Group. All rights reserved. For permission to reuse any of this content visit http://group.bmj.com/group/rights-licensing/permissions.

BMJ Case Report Fellows may re-use this article for personal use and teaching without any further permission.

Become a Fellow of BMJ Case Reports today and you can:

- Submit as many cases as you like

- Enjoy fast sympathetic peer review and rapid publication of accepted articles

- Access all the published articles

- Re-use any of the published material for personal use and teaching without further permission

For information on Institutional Fellowships contact consortiasales@bmjgroup.com

Visit casereports.bmj.com for more articles like this and to become a Fellow 